\title{
Forest flora turnover with climate change in the Mediterranean region: a case study in Southeastern France
}

\author{
VENNETIER Michel $^{(1-2)} *$ and RIPERT Christian ${ }^{(1)}$ \\ * Corresponding author. michel.vennetier@cemagref.fr tel: 33 4.42.66.99.22 FAX: 33 4.42.66.99.23 \\ (1) Cemagref, Aix en Provence, CS 40061, 13182 Aix en Provence Cedex 5 \\ (2) ECCOREV, FR 3098, Aix-Marseille Université, BP 80 F-13545 Aix en Provence cedex
}

\begin{abstract}
This study assessed the turnover in the flora due to climate change in French Mediterranean forests. This turnover was first simulated with a bioclimatic model and then controlled in the field with a flora census in 2008, in permanent plots previously surveyed in 1996-98. The simulation quantified the potential flora turnover for various climate change scenarios. The simulated turnover in the last 30, 20 and 10 years was respectively $11 \%, 14 \%$ and $25 \%$. A rapid turnover was observed in the permanent plots between the two censuses, corresponding to $14 \%$ of the initial plant composition, the last decade being exceptionally hot and dry in the study area. Despite resilience on the landscape scale and
\end{abstract}

\section{Introduction}

The Mediterranean basin will be particularly affected by climate change. Most of the Global Circulation Models forecast faster trends there in the future than in most other regions (Hesselbjerg-Christiansen and Hewitson, 2007): whatever the scenario, warming is likely to be larger in summer, and precipitation is likely to decrease, particularly in spring and summer. As drought is already the main limiting factor for vegetation in the Mediterranean area (Le Houerou, 2005), critical water stress thresholds should be frequently crossed during the growth season, as experienced during 2003 heat and drought (Breda et al., 2006; Ciais et al., 2005).

With increasing temperatures, many species already shifted their ranges to more suitable habitats, moving upwards in elevation or towards the poles (Hughes, 2000; Lenoir et al., 2008), particularly in mountains and at high elevation (Walther et al., 2005). However, certain plants may be unable to adapt to such a rapid change in their environment, nor to follow the shift of the trailing edge in their distribution area. Mean plant spreading distance is short (Clark et al., 1999) in spite of rare events of long distance dispersal, by seed (Clark, 1998; Higgins and Richardson, various resistance strategies, plant composition adaptation to the ongoing climate change seems to take only 20 years on a local scale. Management issues are discussed, particularly biodiversity conservation in current reserve networks, which may be inadequate to ensure long-term species persistence with the rapid shift in plant composition. Most of the areas with the highest plant species richness of the study area potentially disappear when their niche envelopes are mapped using the bioclimatic model with the climate forecasted for year 2050.

\section{Keywords:}

Climate change; flora turnover; resurvey; bioclimatic model; ecological niche; reserves

1999) or by hybridization with heterospecific pollen (Petit et al., 2004). The expected limit shift in the $21^{\text {st }}$ century (Thuiller, 2004) is faster than tree species spread recorded at the end of the last ice age (Delacourt and Delacourt, 1987) and than the sprawling of most invasive plants monitored today (Richardson and Rejmanek, 2004). Species shift should also be checked by biotic interactions (Preston et al., 2008) and competition: symbiotic species and parasites (Moorcroft et al., 2006) should not move at the same rate, endangering the established biological balance. Climate change alters the main stages of plant phenology (Menzel and Fabian, 1999) and sexual reproduction (Hedhly et al., 2009), making them more vulnerable to meteorological extreme events (Morin et al., 2007) and altering plantpollinator interaction.

In Mediterranean low altitude mountains, ecologically fragmented by combined gradients of elevation and orientation, some relicts of Alpine or medio-European vegetation remain in small isolated areas on steep northern slopes near the top (figure 1). They are biologically very rich, mixing species from different biomes (Médail and Quézel, 1999), with a high level of endemism, and genetically original populations. 
Although most of them are protected in reserves, some species may locally disappear because their niche lower limit passes over the local highest elevation (Trivedi et al., 2008b). Moreover, current reserve networks, in the absence of functional corridors, might be inadequate on any scale to ensure long-term persistence of rare and endangered species (Araujo et al., 2004), .

Many models were used to evaluate the shift in plant composition and biodiversity changes, working on potential distribution areas, bioclimatic limits or niches (Botkin et al., 2007; Hansen et al., 2001), for individual species (Gaucherel et al., 2008; Heikkinen et al., 2006) or species groups. Most of these models have a low spatial resolution: the main results were obtained on the scale of countries (Badeau et al., 2004; Chuine and Beaubien, 2001) continents or biomes (Bakkenes et al., 2002; Malcolm et al., 2006) rarely on a more local scale (Trivediet al., 2008b). Uncertainties for each model are high and many discrepancies exist between models (Hampe, 2004; Thuiller, 2003; 2004), due to various parameterization choices, and to the lack of precision of some parameters (Morin and Chuine, 2005).

This is why we developed a new bioclimatic model for mediterranean environments (Vennetier et al., 2008) filling a gap in existing models (Botkinet al., 2007) bridging scales from the region to forest sites $(1 / 4 \mathrm{ha})$ and taking into account both local and global variables (Table 1 ). This model is based on a flora census (see M\&M section). Floristic composition and structure are usually good indicators of site conditions, including climate parameters and their variability and extremes on the middle term (Berges et al., 2006). As the decade 1998-2008 was particularly hot and dry in the study area, including 2003 heat

\section{Material and method}

\subsection{Study area and sampling}

The study area, about $7000 \mathrm{~km}^{2}$ (long $4^{\circ} 5^{\prime}-6^{\circ} 2^{\prime}$ $\mathrm{E}$, lat $43^{\circ} 4^{\prime}, 43^{\circ} 5^{\prime} \mathrm{N}$ ), is situated in the limestonebased Provence, Southeastern France (figure 1). The climate is typically Mediterranean, with a severe summer drought (2-4 months) and mild humid winters. The mean annual temperature and rainfall range respectively from $15.3^{\circ} \mathrm{C} / 500 \mathrm{~mm}$ on the Southwestern coast to $9.5^{\circ} \mathrm{C} / 1000 \mathrm{~mm}$ on the highest ridges (around $1100 \mathrm{~m}$ ), with an average of $13.2^{\circ} \mathrm{C} / 720 \mathrm{~mm}$. Forests are dominated by mixed stands of Pinus halepensis and a persistent drought from 2003 to 2007, one may ask whether these exceptional conditions are reflected in the floristic composition, what the magnitude and rate of change would be, and if so, whether this turnover is significantly biased towards heat and drought tolerant plants.

The aims of this study were (i) to quantify the potential turnover in the plant composition simulated according to various climate change scenarios with our bioclimatic model, (ii) to validate these simulations, comparing the plant census performed in 1996-98 to compute the model and a resurvey in 2008, (iii) to map the potential changes in flora on various landscape scales, as a tool for decision makers and forest managers.

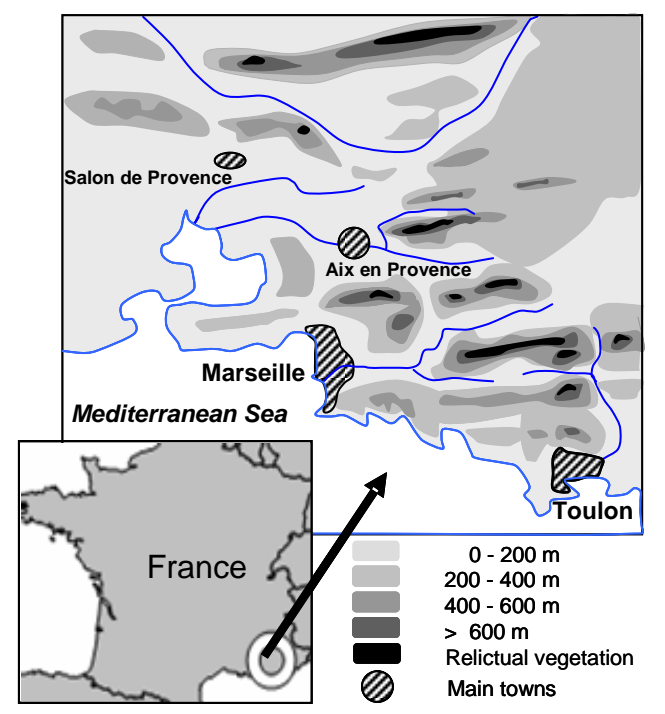

Figure 1: study area. Alpine and medioEuropean relict flora remains on steep north slopes near the top of the highest ridges.

Mill., Quercus ilex L. and Quercus pubescens Will.

A total of 325 circular plots $\left(400 \mathrm{~m}^{2}\right.$ each) were surveyed in years 1996-98, representative of the main ecological gradients and factors including elevation, orientation, distance to the sea, climate type, soil type, topography (Table 1). For each class of the main factors, plots where scattered throughout the study area. In order to minimize the role of disturbances in vegetation response, we selected only: (i) Sites without any wildfire 
since the establishment of the dominant trees, (ii) old (relatively to this ecosystem) and generally uneven-aged forests with dominant trees established more than 70 years ago, (iii) sites with no registered disturbing activity such as logging, grazing, clearing, trampling or prescribed fire over at least the last 30 years. We chose stands with enough openings in the canopy to allow the flora to express itself. A thorough description and measure of site conditions was performed, along with a flora census using a shifted Braun-Blanquet abundance-dominance scale considered as a quantitative one (the "+ ; 1 to 5" scale was shifted to "1 to 6").

\subsection{Model bases}

The model is precisely described in Vennetier et al. (2008). It has been currently used since 2001 to assess and map the forest potential productivity in French Mediterranean regions. In this section, only the bases of the model which are useful for this study are explained. Statistical procedures are described in annex 1. The model computes a bioclimatic index split into two components: a global component based on variables which can be mapped by GIS up to the regional scale, including climatic variables, and a local component based on local variables observed on site scale.

The model was designed in two steps. In the first step, we computed a correspondence analysis (CA) on plant abundance-dominance of the 325 plots, keeping 192 species present in at least 3 plots. It showed that water availability was the main factor driving plant composition in interaction with temperature (figure 2.a): displayed as supplementary variables in the CA plane, all variables related to water balance were significantly correlated with the first axis, which was by far dominant (eigenvalues of the three main axis are respectively 0.086, 0.043, 0.041). Considering its dominance, this first axis was retained alone for modelling and considered as a synthetic bioclimatic gradient. Plants species can be displayed in this plane (figure 2.b). Their coordinate on axis 1 sort them along the water availability and temperature gradient: on the left, the drought and heat tolerant plants (called xerothermophilous) and on the right, plants requiring more water and a cooler climate (called mesophilous), this relative classification being related to the study area. According to this coordinate, we split plant species into five groups of equal number: super xero-thermophilous (sXT), xero-thermophilous (XT), intermediate (Int), slightly mesophilous (Meso) and mesophilous (Meso+).
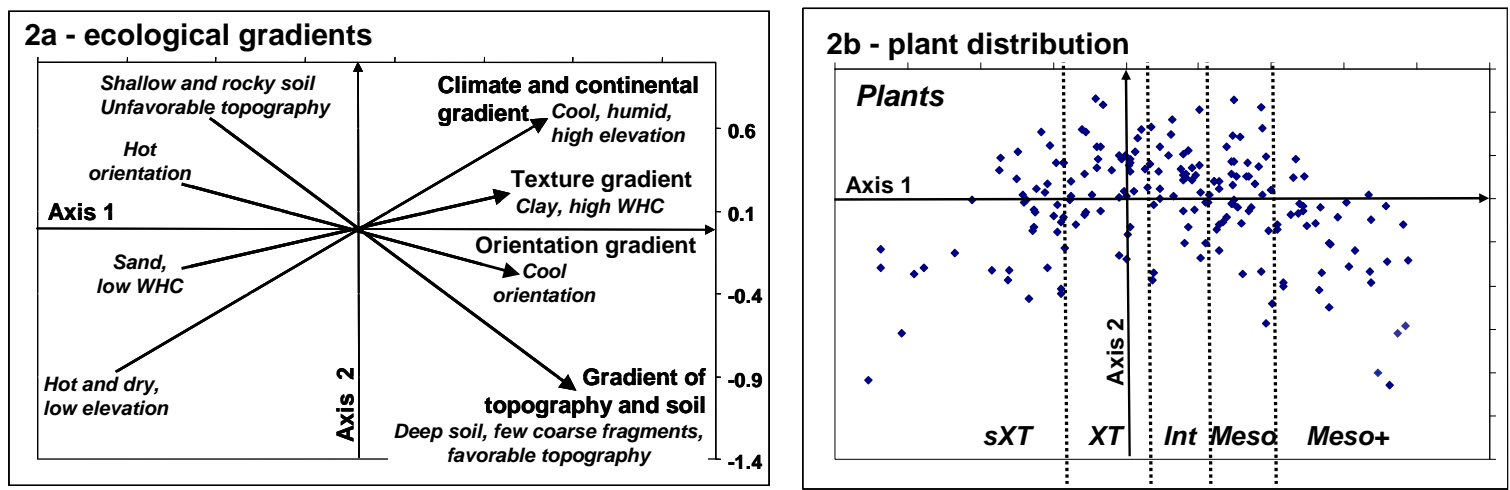

Figure 1: CA main plane

* fig 2a: synthetic representation of four main ecological gradients related to water balance in the study area, interpreted from the distribution of all variables (see table 1) in CA plane: (1) climate and continentality, (2) orientation, (3) soil texture (water holding capacity), (4) topography and soil quality. These gradients were calculated with a linear regression on the coordinates of the classes of concerned variables in the plane. Axis 1 appeared as the synthesis of these 4 gradients, related to water availability and temperature, integrating local and global scales.

* fig 2b: flora distribution in CA plane. Plant species were split into 5 groups (same number of species in each) according to their coordinate on axis 1. 
Plots were displayed in the main CA map. We considered their coordinate on axis 1 as their Flora index (Fi). This index allowed sorting plots along the synthetic bioclimatic gradient.

In the second step, we designed a bioclimatic model based on a PLS regression, computing the estimate of $\mathrm{Fi}$ with abiotic variables describing site conditions. Fi predicted value was chosen as plot bioclimatic index (Bi). The model explained $81 \%$ of Fi variance using height global variables describing climate, geography and aspect plus six local variables describing topography and soil (Table 1). Among used variables, rainfall and the annual mean temperature played a key role. For rainfall, we considered two variables: summer rainfall and, with exactly the same results, whether annual rainfall excluding summer or spring rainfall. In fact, interannual variations of "annual rainfall excluding summer" proved to be mainly due to the variations of spring rainfall 1961-1996 climate values were used for modelling.

The good correlation between the flora index (Fi) and its estimate by the model (Bi) allowed using the model for the assessment of the impact of climate change on plant composition.

Table 1: variables describing site conditions and used for the model

\begin{tabular}{|c|c|c|c|c|}
\hline & Coef $*$ & $\begin{array}{l}\text { Transfor- } \\
\text { mation }\end{array}$ & Variable description & $\begin{array}{l}\text { Gradient } \\
\text { in fig } 2 \mathrm{a}\end{array}$ \\
\hline \multirow{8}{*}{ 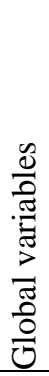 } & -0.183 & $\wedge 2$ & $\begin{array}{l}\text { Becker light-climate index (relative received solar energy in } \% \text { of an } \\
\text { horizontal reference plane) }\end{array}$ & 2 \\
\hline & -0.153 & & Mean annual temperature $\left({ }^{\circ} \mathrm{C}\right)$ & 1 \\
\hline & 0.131 & sigmoid & Altitude (m) & 1 \\
\hline & 0.115 & $\log$ & Summer rainfall : June to August cumulated rainfall (mm) & 1 \\
\hline & 0.082 & & Annual rainfall excluding summer rainfall (mm) or spring rainfall & 1 \\
\hline & 0.169 & \multirow[t]{2}{*}{ polynom } & \multirow{2}{*}{$\begin{array}{l}\text { Maximum altitude between a site and the coastline in two directions: the } \\
\text { closest coast line and } 247^{\circ}(\mathrm{m})\end{array}$} & \multirow[t]{2}{*}{1} \\
\hline & 0.146 & & & \\
\hline & 0.106 & sigmoid & Distance to the sea $(\mathrm{km})$ & 1 \\
\hline \multirow{6}{*}{ 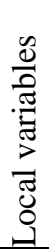 } & -0.136 & & General topography on landscape and slope scale (5 classes scale) & 4 \\
\hline & -0.107 & & Topography on local scale (plot size) (5 classes scale) & 4 \\
\hline & -0.083 & & Percentage of parent rock outcrops on the plot & 4 \\
\hline & 0.100 & & Water holding capacity of earth $(\mathrm{mm} / \mathrm{cm})$ based on soil texture & 3 \\
\hline & -0.091 & & Percentage of coarse fragments in the soil & 4 \\
\hline & 0.119 & $\log$ & Total soil depth (cm) & 4 \\
\hline
\end{tabular}

* Coef. = Partial regression coefficient in the PLS regression model. All theses coefficients are highly significant $(\mathrm{P}<0.001)$.

\subsection{Simulation of climate change impact on plant turnover}

The simulation used the two steps of the model: First, we considered that an increasing mean annual temperature or decreasing spring or summer rainfall would favour sXT and XT groups, and stress the Meso and Meso+ ones. We simulated this impact, changing at plant distribution margins of each plot (1) the composition or (2) the abundance-dominance:

- (1) elimination of one to three plant species of the observed flora of the plot, those with the highest coordinates on CA first axis, and addition of one to three plant species, not previously observed in the plot, those with the closest coordinates to the actual minimum of this plot. This simulation led to a plant composition turnover which was calculated as a percentage of the actual listed flora.
(2) respectively decrease / increase of the BraunBlanquet coefficients of one to three of the plants species with respectively the highest / smallest coordinates of each plot.

Using these modified plots as supplementary observations in the initial CA, we computed the new coordinates of each plot on axis 1 , which means new and smaller Fi indices (modified plots shifted to the left in the CA plane).

In the second step, climatic variables were changed according to various climate change scenarios: we simulated (i) rainfall decrease alone (spring or summer or both), (ii) temperature increase alone (1 to $2^{\circ} \mathrm{C}$ ) and (iii) various combined rainfall and temperature, including the mean climate observed over respectively the last 10, 20 and 30 years (1978-2007). New and smaller Bi indices for each plot were computed. 
The good correlation between initial $\mathrm{Fi}$ and $\mathrm{Bi}$ indices enabled linking the respective shift, and therefore assessing the plant composition turnover expected for each climate scenario. In this study, we considered the flora as a whole and did not focus on individual species.

\subsection{Validation with a new flora census}

Fifty plots of the initial census, chosen to cover

\section{Results}

\subsection{Simulation of plant composition turnover}

The average number of plants in our plots was 25 $(8-57, S D=8)$, unchanged in the last 10 years.

A $20 \%$ reduction of spring or summer rainfall would correspond to a 4 to $5 \%$ turnover, that is to say only 1 plant species, rarely 2, that would change among 25 (figure 3). An increase of $1^{\circ} \mathrm{C}$ would be more disturbing ( $7 \%$ turnover), and combined with a $10 \%$ loss of spring or summer rainfall could change $10 \%$ of plant composition. the whole span of the four main ecological gradients (figure 2.a) and scattered throughout the study area were chosen for a new flora census in 2008. This census was performed by the same team using exactly the same protocols. Flora variations between the two sampling dates were analysed highlighting the differences between the five plant groups.

\begin{tabular}{|c|c|c|c|c|c|}
\hline $\begin{array}{l}\text { Spring } \\
\text { rainfall }\end{array}$ & $\begin{array}{r}-10 \% \\
-20 \%\end{array}$ & \multirow{2}{*}{$\begin{array}{r}-10 \% \\
\text { and }\end{array}$} & & \multirow{3}{*}{$\begin{array}{c}-10 \% \\
\text { and } \\
-10 \% \\
\text { and } \\
+2^{\circ} \mathrm{C} \\
\end{array}$} & \multirow{2}{*}{\begin{tabular}{|l}
$-18 \%$ \\
and \\
$-32 \%$ \\
and
\end{tabular}} \\
\hline $\begin{array}{l}\text { Summer } \\
\text { rainfall }\end{array}$ & $\begin{array}{r}-10 \% \\
-20 \%\end{array}$ & & & & \\
\hline $\begin{array}{l}\text { Temp. }\left({ }^{\circ} \mathrm{C}\right) \\
\text { annual }\end{array}$ & & $+1^{\circ} \mathrm{C}$ & $+2^{\circ} \mathrm{C}$ & & $+1.4^{\circ} \mathrm{C}$ \\
\hline & 5 & 10 & 15 & 20 & 25 \\
\hline
\end{tabular}

The average climate of respectively the last 30 , 20 and 10 years led to a potential $11.5 \%, 14 \%$ and $25 \%$ plant species turnover.

For a given plot, an increase / decrease of 2 points of the Braun-Blanquet coefficient for a plant which coordinate on CA first axis is close to respectively the minimum or the maximum within this plot was equivalent to a 5\% occurrence turnover (+/- one plant species).

\subsection{Comparison with the observed shift in plant composition}

The observed shift did not occur at random but was biased towards axis 1 bioclimatic gradient (figure 4).

Figure 3: Variation between 1996-98 and 2008 of the occurrence of plants according to their water stress and heat tolerance, as a percentage of the number plants per group. Winners / loosers means plant species respectively present in more / less plots in 2008 than in 1996-98.

In the Meso+ group, $50 \%$ of plant species lost ground, disappearing from plots (loosers), far more than in the sXT group (only 20\%). On the opposite, only $10 \%$ of the Meso+ plants were found in new plots compared with $40 \%$ of the
Figure 2: Simulated flora turnover (percentage of the original flora) fitted with simulated climate changes. The last box on the right corresponds to the mean climate of the last 10 years.

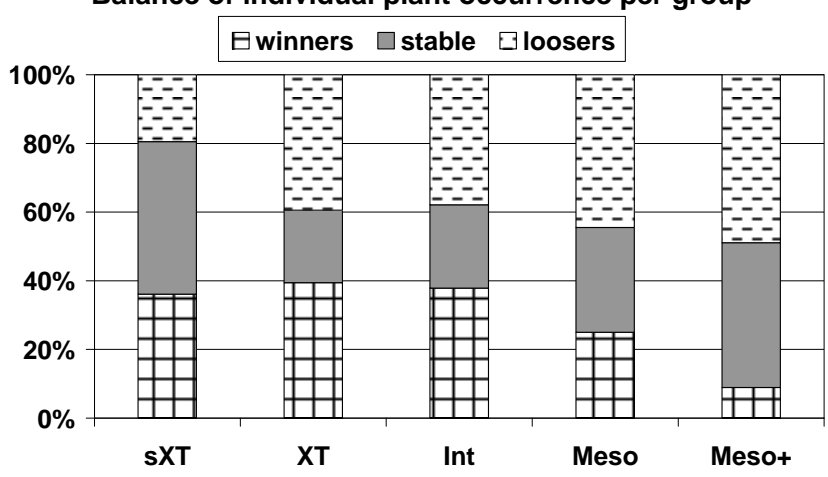

sXT plants. In the Meso group, loosers are 20\% more numerous than winners.

Changes in XT and intermediate groups were balanced, species of the same group appearing or disappearing at the same rate. 
The differences between the two extreme groups were also clear from the sum of species occurrence per group and were even more considerable when considering the sum of Braun-Blanquet coefficients (figure 5).

Figure 4: variations between 1996-98 and 2008 of the sums of occurrences and Braun-Blanquet coefficients per group in the 50 plots revisited in 2008. One occurrence $=$ one species in one plot.

The sXT and XT groups together won 70 occurrences, corresponding to 1.5 plants per plot. But their sum of Braun-Blanquet coefficients won 120 points, nearly 2.5 points per plot. It means that not only new xero-thermophilous plants appeared in plots but also that some plants of these groups, already present in 1996-98, increased in dominance and cover. Meso + and Meso plants lost together 70 occurrences and just a bit more in the sum of Braun-Blanquet coefficients, which means that, for these two groups, losses in cover were mainly due to losses in occurrence. Globally the occurrence turnover, biased towards xero-thermophyllous plants, reached 3 plants, equivalent to $12 \%$ in 10 years. Variations in the sum of Braun-Blanquet coefficients which are not explained by occurrence variations must be taken into account. When their equivalent in occurrences was added (one occurrence for 2 points of coefficients), the total observed turnover was close to $14 \%$.

\section{Discussion}

\subsection{Validating and quantifying vegetation turnover}

A 5 to $10 \%$ change in plant composition between two following censuses in the same plot is common without any environmental change (Archaux et al., 2006). But in such a case this change is not related to a specific gradient, as plants within a given group replace each other, all groups being concerned at the same level. In this study, the observed plant turnover patterns were very close to those we used to simulate climate change impact with our model: the most mesophilous and xero-thermophilous plants (SXT and Meso+ groups) were far more concerned than intermediate ones, respectively loosing or gaining

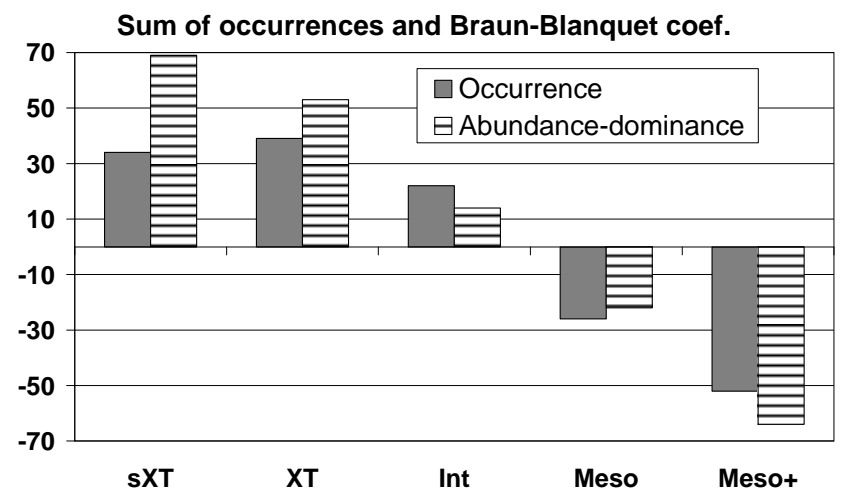

\subsection{Mapping Bi index on various scales}

Bi index computed with global variables was mapped with a GIS software after being split into nine classes (figure 6.a). Each class included 1/9 of Bi total variation interval after exclusion of the $5 \%$ extreme values (2.5\% at each end). These extreme values were merged with the first and last classes respectively. Range limits of various species match some of these classes. For example the darkest green (class 9) corresponds to the observed niche of Scots pine and related alpine and meso-European relict species, and excludes Pinus halepensis because of deep frost in winter. On average soil conditions and with a neutral topography, class 2 (pink) is the lowest limit of Quercus pubescens. In the same conditions, classes 1 to 4 (red to yellow) allow only a poor growth of Pinus halepensis, while this growth is good in classes 6 to 8 (blue to medium green) (Vennetier, 2007).

several species per plot which validates our simulation method.

This trend can be related to a global shift of vegetation composition towards heat and drought resistant plants. It is not linked to the evolution of aging forest structures. Indeed, in Southern Europe the Mediterranean ecosystems were transformed by several thousands years of disturbances and development (Blondel and Aronson, 1999). Although we selected relatively old (for the local context) and unmanaged stands, most of them were probably partly cultivated or at least impacted by grazing, logging and controlled fires up to the beginning of the $19^{\text {th }}$ century. Their natural evolution, as it was observed up to the end of the $20^{\text {th }}$ century, (Tatoni and Roche, 1994) should be mainly a 
maturation process leading to an increasing dominance of mesophilous and shade tolerant plants and the reduction of light demanding, generally xero-thermophilous species, inherited from past land uses. The opposition between this natural trend and the one we measured in this study strengthens the probability of a strong relation between the recent species turnover and climate change.

Probably, the adverse climate conditions in the last decade also contributed indirectly to a hotter and drier microclimate in the undergrowth, limiting canopy density though tree mortality (Allen et al., 2009), low branching rates and reduced leaf area (Thabeet et al., 2009). In the study area, the difference between the average climate of the last 10 years and the previous 30 years $\left(+1.4^{\circ} \mathrm{C},-18 \%\right.$ in spring rainfall and $-32 \%$ in summer rainfall, see figure 3 ) is surprisingly equivalent to the evolution forecasted for the next 30 to 40 years by IPCC medium scenarios (I.P.C.C., 2007). This exceptional period will probably not last far longer, and the 2004-2007 repeated severe droughts were restricted to Provence region. This unique unexpected result was interesting as it allowed assessing what may happen in other regions and in the study area in the future. The $25 \%$ turnover we forecasted on plot scale if the climate of the last decade remained stable can be compared to results of previous studies on larger scales: Bakkenes et al (2002) showed that $32 \%$ of the European plant species that are present in a grid cell of a few square kilometres in 1990 should disappear from that cell before 2050. High rates of potential extinction among endemic species (average 11\%, up to $43 \%$ ) were forecasted by Malcolm et al. (2006) for the whole Mediterranean basin and other biodiversity hotspots in the world by 2100 .
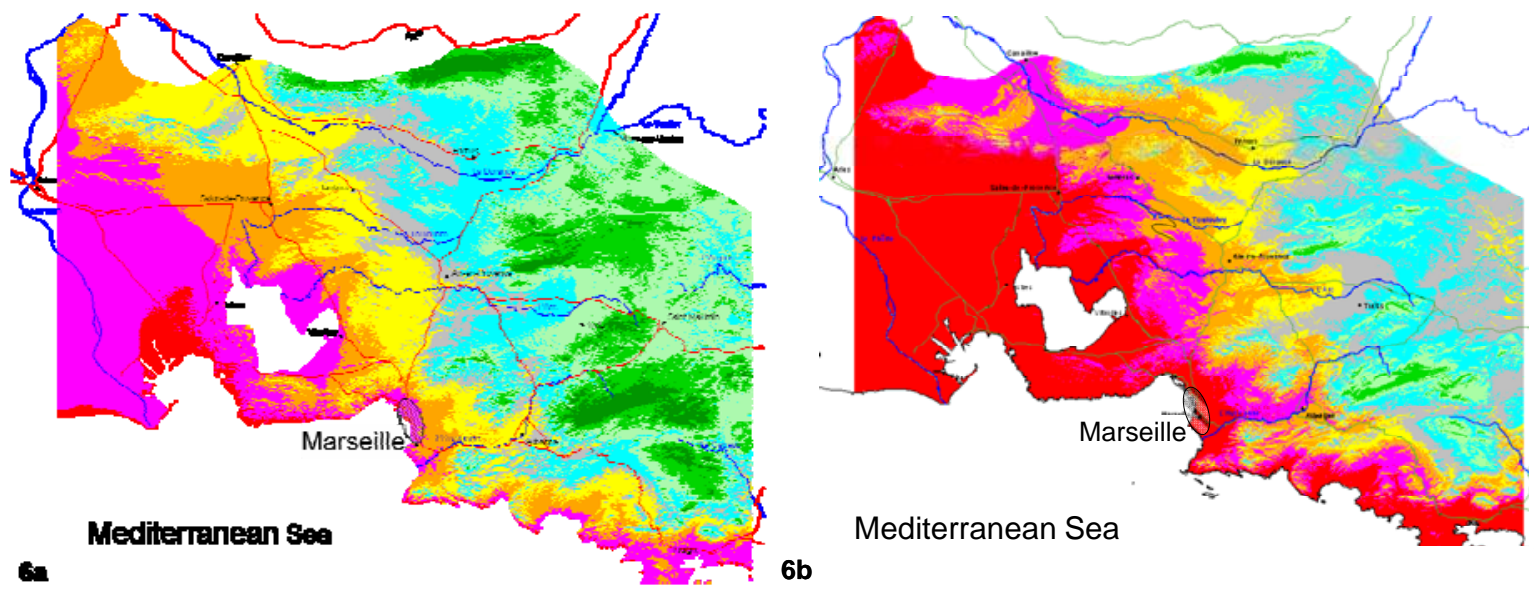

\begin{tabular}{|l|l|l|l|l|l|l|l|l|l|}
\hline Colour & & & & & & & & & \\
\hline Bi class & 1 & 2 & 3 & 4 & 5 & 6 & 7 & 8 & 9 \\
\hline
\end{tabular}

Figure 5: Bioclimatic index (Bi) computed with global variables and mapped on regional scale with ArcGis 0 software in 9 classes of equal Bi index span. The darkest green (class 9) corresponds to the potential niche of Scots pine and related alpine and meso-European relict species. The three shades of green together draw the area of the supra-Mediterranean bioclimate, the blue to pink intermediate colors the meso-Mediterranean and the red the thermo-Mediterranean bioclimate (Emberger, 1930).

6a: Map with 1961-96 mean climate.

6b: Map with 2050 climate (IPCC, B2 Scenario). Relict vegetation has no potential niche left in the study area. Q. pubescens should move away far from the coast, and the growth of $P$. halepensis been slower in most of the study area.

\subsection{Flora resistance on landscape and local scales}

The turnover in the flora observed in the last decade was half of the one predicted by the model for the same period, and equal to the one predicted with the climate of the last 20 years.
Thus, plant composition showed a partial resistance to climate variations, as ten years were not enough to achieve the potential changes. Adapting to new climatic conditions may take about 20 years, including some extreme events (scorching heat, repeated droughts). 
Part of this resistance may be due to the landscape structure. When mapped on any scale with a GIS, the Bi index computed with global variables showed that the study area is a patchwork of fragmented bioclimatic classes (figure 6.a). On the scale of a small hill $(1 \mathrm{x} 1 \mathrm{~km})$ with steep slopes, when considering global and local variables, six among the nine classes represented on regional scales can be found. Thanks to that fine grain mosaic, xerothermophilous plants are already scattered in areas with a rather wet climate and at high elevation, taking advantage of steep south-facing slopes, shallow and rocky soils, or simply remaining from former land uses and fires. They can easily spread from these advanced bases when mesophilous species become less competitive because of climate change.

On the contrary, mesophilous species may survive in the most favourable sites like valleys, north-facing slopes and on deep soils, and come back by seed dispersal in favourable years. Moreover, the Mediterranean flora is particularly adapted to frequent and severe stresses. It is dominated by woody species, and includes many plants selected by fire and therefore possessing large amounts of underground reserves to resprout. Several unfavourable years are required to deplete these reserves. Plants have other survival strategies, including long lifespan, soil seed-banks (Zobel et al., 2007) and partial mortality limiting their leaf area. Their elimination from large areas requires time. However, the extensive dieback of some dominant tree species like Scots pine (Pinus silvestris L.) in the French Mediterranean area (Vennetier et al., 2009) suggests that the most mesophilous species are really at risk in these regions.

\subsection{Management issues}

Located at the very limit of their distribution range, many remnants of Alpine or medioEuropean flora, protected in Mediterranean mountain reserves, should be the first to disappear as it was suggested in our study and shown in figure 6.b. It confirms what was found by Trivedi et al. (2008a) in low mountain ranges similar to our study area, where 70 to $80 \%$ of plant species should lose most of their suitable climate space in the next 100 years. These authors showed that larger scale approaches may underestimate the potential climate-based disappearance by far. Moreover, a low spatial cohesion of the habitat, below the critical level of metapopulation persistence, should increase the probability of extreme weather events to cause larger gaps in already scattered populations (Opdam and Wascher, 2004).

In view of the rapid turnover observed in our study area, an adaptation policy is required in the next 20 years. For the smallest isolated areas of relict forest vegetation, which should be soon kicked out by the top, ex-situ conservation of endemic and rare species should be urgently implemented. For example, more than $50 \%$ of very low elevation scattered Scots pine stands, far more resistant to heat and drought than most other origins of this species, were killed by 2003 heat which passed a critical threshold, and their remnants are in poor conditions. This specific genetic resource may soon be lost.

Other protected areas are generally included in developed lands. Although the majority of recommendations in the published literature lack sufficient specificity to operationalize them, Heller and Zavaleta (2009) highlighted the potential role of public and private multi-use lands in conservation practices. Foresters should work with other land managers to establish corridors, and to look for the parts of these human-dominated landscapes that should be suitable for forest species. Bioclimatic maps like figure 6, if regularly updated, could help designing such strategies.

Some other key management issues concern dominant tree species and forest productivity. According to the model, Quercus pubescens limit should move away from the coast. Thus high rates of die-back are expected in low altitude matorals, leading to an increased fire risk due to dead fuel accumulation. As shown in figure6.b, bioclimatic classes limiting Pinus halepensis productivity should become dominant in the study area, which may hamper the already weak wood-based economy. 


\section{Conclusion}

In this study, we verified the hypothesis that a rapid turnover in the flora was under way on site scale in Mediterranean forests. The adaptation time of plant composition to the current climate change seems to be close to 20 years in the study area, according to the comparison of simulated data and field validation. Conservation policies for rare and endangered species and more generally conservation policies based on fixed reserve networks should soon be reconsidered, particularly in Mediterranean mountains. It is all the more necessary since climate change may accelerate in the future.

For hilly or mountainous areas with highly fragmented niches and bioclimatic envelopes, the assessment of climate change impact on national or continental scales seems unrealistic. The right scale for an operational assessment of the shift in plant composition is close to landscape structure and linked to mean seed dissemination distance. Models should include detailed topographic and soil variables. Soil maps are rarely available in forest areas, but they can be simulated from soil types distribution models on landscape scale (Scull et al., 2003) and local validation and calibration tests (Lagacherie et al., 1995).

Therefore, such assessments on an operational scale should be multiplied in the main ecosystems and regions, so that large scale approaches could be corrected and better interpreted. Small scales approaches, tailored to specific needs, also enhance local knowledge and encourage dissemination and decision making at operational forest management level. Ecological as well as economical issues are at stake.

In our study, the climate-driven turnover in the flora was assessed statistically in permanent plots. Many parameters including the real species migration capacity, population dynamics, biotic interactions and community ecology should be taken into account (Brooker et al., 2007; Guisan and Thuiller, 2005) to improve the spatial assessment of plant migration and turnover on a landscape scale.

\section{Aknowledgements}

The initial flora census (1996-98) and model design was funded by the French Ministry for Agriculture and Fisheries. Several students and technicians contributed to field work particularly Jean S., Estève R., Chandioux O., Martin W.

\section{References}

Allen, C.D., Macalady, A.K., Chenchouni, H., Bachelet, D., Mcdowell, N., Vennetier, M., Kitzberger, T., Rigling, A., Breshears, D.D., Hogg, E.H., Gonzalez, P., Fensham, R., Zhang, Z., Castro, J., Demidova, N., Lim, J.-H., Allard, G., Running, S.W., Semerci, A., Cobb, N., 2009. A Global Overview of Drought and Heat-Induced Tree Mortality Reveals Emerging Climate Change Risks for Forests, For. Ecol. Manag., in press (2009), doi:10.1016/j.foreco.2009.09.001.

Amato, S., Vinzi, V.E., 2003. Bootstrap-based Q2kh for the selection of components and variables in PLS regression, Chemom. Intell. Lab. Syst., (68): 5-16.

Araujo, M.B., Cabeza, M., Thuiller, W., Hannah, L., Williams, P.H., 2004. Would climate change drive species out of reserves? An assessment of existing reserve-selection methods, Glob. Chang. Biol., (10) 9: 1618-1626.

Archaux, F., Berges, L., Chevalier, R., 2007. Are plant censuses carried out on small quadrats more reliable than on larger ones?, Plant Ecol., 188: 179-190.

Archaux, F., Gosselin, F., Berges, L., Chevalier, R., 2006. Effects of sampling time, species richness and observer on the exhaustiveness of plant censuses, J. Veget. Sci., (17): 299-306.

Badeau, V., Dupouey, J.-L., Cluzeau, C., Drapier, J., Le Bas, C., 2004. Projet CARBOFOR. Tâche D1 : Modélisation et cartographie de l'aire climatique potentielle des grandes essences forestières françaises INRA, Inventaire forestier national, Nancy. 49 p.

Bakkenes, M., Alkemade, J.R.M., Ihle, F., Leemans, R., Latour, J.B., 2002. Assessing effects of forecasted climate change on the diversity and distribution of European higher plants for 2050, Glob. Chang. Biol., (8) 4: 390-407.

Berges, L., Gegout, J.C., Franc, A., 2006. Can understory vegetation accurately predict site index? A comparative study using floristic and abiotic indices in sessile oak (Quercus petraea Liebl.) stands in northern France, Ann. For. Sci., (63) 1: 31-42.

Blondel, J., Aronson, J., 1999. Biology and wildlife of the Mediterranean region, Oxford University Press, Oxford. 
Vennetier, M., Ripert, C., Forest flora turnover with climate change in the Mediterranean region: A case study in Southeastern France. Preprint version of the original paper: For. Ecol. Manage. (2009), doi:10.1016/j.foreco.2009.09.015.

Botkin, D.B., Saxe, H., Araujo, M.B., Betts, R., Bradshaw, R.H.W., Cedhagen, T., Chesson, P., Dawson, T.P., Etterson, J.R., Faith, D.P., Ferrier, S., Guisan, A., Hansen, A.S., Hilbert, D.W., Loehle, C., Margules, C., New, M., Sobel, M.J., Stockwell, D.R.B., 2007. Forecasting the effects of global warming on biodiversity, Biosci., (57) 3: 227236.

Breda, N., Huc, R., Granier, A., Dreyer, E., 2006. Temperate forest trees and stands under severe drought: a review of ecophysiological responses, adaptation processes and long-term consequences, Ann. For. Sci., (63) 6: 625-644.

Brooker, R.W., Travis, J.M.J., Clark, E.J., Dytham, C., 2007. Modelling species' range shifts in a changing climate: The impacts of biotic interactions, dispersal distance and the rate of climate change, J. Theor. Biol., (245) 1: 59-65.

Chuine, I., Beaubien, E.G., 2001. Phenology is a major determinant of tree species range, Ecol. Lett., (4) 5: 500-510.

Ciais, P., Reichstein, M., Viovy, N., Granier, A., Ogee, J., Allard, V., Aubinet, M., Buchmann, N., Bernhofer, C., Carrara, A., Chevallier, F., De Noblet, N., Friend, A.D., Friedlingstein, P., Grunwald, T., Heinesch, B., Keronen, P., Knohl, A., Krinner, G., Loustau, D., Manca, G., Matteucci, G., Miglietta, F., Ourcival, J.M., Papale, D., Pilegaard, K., Rambal, S., Seufert, G., Soussana, J.F., Sanz, M.J., Schulze, E.D., Vesala, T., Valentini, R., 2005. Europe-wide reduction in primary productivity caused by the heat and drought in 2003, Nature, (437) 7058: 529-533.

Clark, J.S., 1998. Why trees migrate so fast: Confronting theory with dispersal biology and the paleorecord, Am. Nat., (152) 2: 204-224.

Clark, J.S., Silman, M., Kern, R., Macklin, E., Hillerislambers, J., 1999. Seed dispersal near and far: Patterns across temperate and tropical forests, Ecology (80) 5: 1475-1494.

Delacourt, P., Delacourt, H., 1987. Long-term Forest Dynamics of the Temperate Zone, Springer, New York.

Emberger, L., 1930. La végétation de la région méditerranéenne : essai d'une classification des groupements végétaux, Rev. Gén. Bot., 42: 641-662, 705-721.

Escofier, B., Pages, J., 1994. Multiple Factor analysis, Comput. Stat. \& Data Anal., 18: 121-140.

Gaucherel, C., Guiot, J., Misson, L., 2008. Changes of the potential distribution area of French Mediterranean forests under global warming, Biogeosci., (5) 6: 1493-1504.

Good, P., 1994. Permutation tests, Springer-Verlag, New-York.

Guiot, J., 1991. Methods and programs of statistics for palaeoclimatology and palaeoecology. In: Quantification des changements climatiques. Méthodes et Programmes, Monographie 1. Marseille: INSU, Paris, 1991, pp. 258.

Guisan, A., Thuiller, W., 2005. Predicting species distribution: offering more than simple habitat models, Ecol. Lett., (8) 9: 993-1009.

Hampe, A., 2004. Bioclimate envelope models: what they detect and what they hide, Glob. Ecol. Biogeog., (13) 5: 469-471.

Hansen, A.J., Neilson, R.R., Dale, V.H., Flather, C.H., Iverson, L.R., Currie, D.J., Shafer, S., Cook, R., Bartlein, P.J., 2001. Global change in forests: Responses of species, communities, and biomes, Biosci., (51) 9: 765-779.

Hedhly, A., Hormaza, J.I., Herrero, M., 2009. Global warming and sexual plant reproduction, Trends Plant Sci., (14) 1: 30-36.

Heikkinen, R.K., Luoto, M., Araujo, M.B., Virkkala, R., Thuiller, W., Sykes, M.T., 2006. Methods and uncertainties in bioclimatic envelope modelling under climate change, Progr. Phys. Geog., (30) 6: 751-777.

Heller, N.E., Zavaleta, E.S., 2009. Biodiversity management in the face of climate change: A review of 22 years of recommendations, Biol. cons., (142) 1: 14-32.

Hesselbjerg-Christiansen, J., Hewitson, B., 2007. Regional Climate Projection. In: IPCC (2007) Climate Change 2007: The Physical Science Basis. Contribution of Working Group I to the Fourth Assessment Report of the Intergovernmental Panel on Climate Change. Solomon, S., D. Qin, M. Manning, Z. Chen, M. Marquis, K.B. Averyt, M. Tignor and H.L. Miller eds., Cambridge University Press, Cambridge, United Kingdom and New York, NY, USA. chap 11, pp 847-940.

Higgins, S.I., Richardson, D.M., 1999. Predicting plant migration rates in a changing world: The role of long-distance dispersal, Am. Nat., (153) 5: 464-475.

Hughes, L., 2000. Biological consequences of global warming: is the signal already apparent?, Trends Ecol. Evol., (15) 2: 56-61.

I.P.C.C., 2007. Climate Change 2007: The Physical Science Basis. Contribution of Working Group I to the Fourth Assessment Report of the Intergovernmental Panel on Climate Change. Solomon, S., Qin, D., Manning, M., Chen, Z., Marquis, M., Averyt, K.B., Tignor, M., Miller, H.L. eds, Cambridge University Press, Cambridge, United Kingdom and New York, NY, USA. 
Vennetier, M., Ripert, C., Forest flora turnover with climate change in the Mediterranean region: A case study in Southeastern France. Preprint version of the original paper: For. Ecol. Manage. (2009), doi:10.1016/j.foreco.2009.09.015.

Lagacherie, P., Legros, J.P., Burrough, P.A., 1995. A Soil Survey Procedure Using the Knowledge of Soil Pattern Established on a Previously Mapped Reference Area, Geoderma, (65) 3-4: 283-301.

Le Houerou, H.N., 2005. The Isoclimatic Mediterranean Biomes: Bioclimatology, Diversity and Phytogeography. Vol. 1 \& 2, Copymania Publication, Montpellier.

Lenoir, J., Gegout, J.C., Marquet, P.A., De Ruffray, P., Brisse, H., 2008. A significant upward shift in plant species optimum elevation during the 20th century, Science, (320) 5884: 1768-1771.

Malcolm, J.R., Liu, C.R., Neilson, R.P., Hansen, L., Hannah, L., 2006. Global warming and extinctions of endemic species from biodiversity hotspots, Conserv. Biol., (20) 2: 538-548.

Médail, F., Quézel, P., 1999. Biodiversity Hotspots in the Mediterranean Basin: Setting Global Conservation Priorities, Conserv. Biol., (13) (6): 1510 -1513.

Menzel, A., Fabian, P., 1999. Growing season extended in Europe, Nature, (397) 6721: 659-659.

Moorcroft, P.R., Pacala, S.W., Lewis, M.A., 2006. Potential role of natural enemies during tree range expansions following climate change, J. Theor. Biol., (241) 3: 601-616.

Morin, X., Ameglio, T., Ahas, R., Kurz-Besson, C., Lanta, V., Lebourgeois, F., Miglietta, F., Chuine, I., 2007. Variation in cold hardiness and carbohydrate concentration from dormancy induction to bud burst among provenances of three European oak species, Tree Physiol, (27) 6: 817-25.

Morin, X., Chuine, I., 2005. Sensitivity analysis of the tree distribution model PHENOFIT to climatic input characteristics: implications for climate impact assessment, Glob. Chang. Biol., (11) 9: 1493-1503.

Opdam, P., Wascher, D., 2004. Climate change meets habitat fragmentation: linking landscape and biogeographical scale levels in research and conservation, Biol. cons., (117) 3: 285-297.

Petit, R.J., Bodenes, C., Ducousso, A., Roussel, G., Kremer, A., 2004. Hybridization as a mechanism of invasion in oaks, New Phytol., (161) 1: 151-164.

Preston, K., Rotenberry, J.T., Redak, R.A., Allen, M.F., 2008. Habitat shifts of endangered species under altered climate conditions: importance of biotic interactions, Glob. Chang. Biol., (14) 11: 2501-2515.

R_Development_Core_Team, 2004. R: A language and environment for statistical computing. R Foundation for Statistical Computing, R Foundation for Statistical Computing.

Richardson, D.M., Rejmanek, M., 2004. Conifers as invasive aliens: a global survey and predictive framework, Divers. Distrib., (10) 5-6: 321-331.

Scull, P., Franklin, J., Chadwick, O.A., Mcarthur, D., 2003. Predictive soil mapping: a review, Progr. Phys. Geog., (27) 2: 171-197.

Tatoni, T., Roche, P., 1994. Comparison of Old-Field and Forest Revegetation Dynamics in Provence, J. Veget. Sci., (5) 3: 295-302.

Thabeet, A., Vennetier, M., Gadbin-Henry, C., Denelle, N., Roux, M., Caraglio, Y., Vila, B., 2009. Response of Pinus sylvestris L. to recent climate change in the French Mediterranean region, Trees Struct. Funct., (28) 4: 843-853.

Thioulouse, J., Chessel, D., Doledec, S., Olivier, J.M., 1997. ADE-4: a multivariate analysis and graphical display software, Stat. Comput., 7: 75-83.

Thuiller, W., 2003. BIOMOD - optimizing predictions of species distributions and projecting potential future shifts under global change, Glob. Chang. Biol., (9) 10: 1353-1362.

Thuiller, W., 2004. Patterns and uncertainties of species' range shifts under climate change, Glob. Chang. Biol., (10) 12: 2020-2027.

Trivedi, M.R., Berry, P.M., Morecroft, M.D., Dawson, T.P., 2008a. Spatial scale affects bioclimate model projections of climate change impacts on mountain plants, Glob. Chang. Biol., (14) 5: 1089-1103.

Trivedi, M.R., Morecroft, M.D., Berry, P.M., Dawson, T.P., 2008b. Potential effects of climate change on plant communities in three montane nature reserves in Scotland, UK, Biol. cons., (141) 6: 1665-1675.

Vennetier, M., 2007. Un nouveau modèle bioclimatique pour la forêt méditerranéenne. Application à l'étude de l'impact du changement climatique sur la végétation et à l'évaluation de la productivité forestière, Thèse de doctorat, UR Ecosystèmes méditerranéens et risques, Cemagref / Université Paul Cézanne (Aix-Marseille III) Aix en Provence. $284 \mathrm{p}$.

Vennetier, M., Ripert, C., Maillé, E., Blanc, L., Torre, F., Roche, P., Tatoni, T., Brun, J.-J., 2008. A new bioclimatic model calibrated with flora for Mediterranean forested areas, Ann. For. Sci., (65) 711.

Vennetier, M., Thabeet, A., Gadbin-Henry, C., Ripert, C., Prévosto, B., Borgniet, L., Vila, B., Guibal, F., Ray, R., Buron, V., Zanetti, C., 2009. Conséquences de la canicule et de la sécheresse 2003 sur les pins méditerranéens. In: 
Landman, G., Landeau, S. (eds.), Sécheresse et canicule 2003. Contribution des dispositifs de suivi et d'observation des forêts à la quantification des effets immédiats et à court terme. Paris: ECOFOR, 2009, pp. in press.

Walther, G.R., Beissner, S., Burga, C.A., 2005. Trends in the upward shift of alpine plants, J. Veget. Sci., (16) 5: 541548.

Zobel, M., Kalamees, R., Püssa, K., Roosaluste, E., Moora, M., 2007. Soil seed bank and vegetation in mixed coniferous forest stands with different disturbance regimes, For. Ecol. Manag., (250) 1-2: 71-76.

\section{Annex 1: statistical procedures}

We used a classical unweighted CA analysis with Braun-Blanquet coefficients to obtain the Flora index as the coordinates of plots on the first CA axis. We checked the robustness of the CA axes towards potential inaccuracies of floristic censuses due to time or spatial strategies or the observer (Archaux et al., 2007; Archauxet al., 2006) and towards analyses options. This verification was performed with a Multiple Factorial Analysis (MFA) (Escofier and Pages, 1994) testing the stability of CA axes and plots coordinates: on one hand by increasing the number of plots where a plant must be present to be taken into account from 3 to 30, on the other hand comparing presence/absence and BraunBlanquet coefficients in the analysis.

CA axes 1 to 3 and plots coordinates proved to be particularly stable ( $\mathrm{r}^{2}$ of plot rank on axis $1>$ $98 \%$ ) whatever the code used (BB coefficients or presence/absence) and up to a limit of 25 occurrences for plant selection.

Some variables seemed to have non-linear relationship with the Flora index (Fi). To optimize the PLS model, we first checked the relation pattern of all relevant variables with $\mathrm{Fi}$ using neural networks and transformed some of them (log, sigmoidal or polynomial). Neural networks where used combining variables 6 by 6 . Each neural network was optimized with a 200 replications bootstrap, each replication including $10^{\wedge} 4$ calibration steps. After the optimization of the neural network, the response of each variable was plotted on its whole variation interval, the other variables being maintained at their mean value if they were not correlated with the tested one, or maintained successively to their first, second and third quartile for those which were correlated.
In the last case, the 3 responses where combined in a sliding weighted mean to obtain the global response. We only transformed a variable according to non-linear relation showed by neural networks when this relation was stable throughout these many tests and enhanced as well (i) the weight of the variable in the neural network optimization and (ii) its partial correlation coefficient or the total explained variance in the PLS regression.

For the choice of relevant variables in the model, we used an ascending and descending stepwise PLS regression validated at each step by a permutation test on PLS components and a crossvalidation for concerned variables. All variables in the final version of the model were highly significant on the first two PLS components ( $p<$ $0.001)$. The number of significant components for PLS regression was chosen with a 10,000 replications permutation test on observations (Good, 1994), keeping components which percentage of explained variance was not passed by more than $5 \%$ of the permutations. With significant components, variables were sorted through a 1,000 resampling cross-validation test (Amato and Vinzi, 2003) ; only variables which confidence interval (95\%) for the partial correlation coefficient excluded 0 were used.

We used ADE4 software (Thioulouse et al., 1997) for CA and related operations (introducing supplementary observations and variables), for MFA and PLS permutation tests, Statgraphics ${ }^{\circledR}$ software for stepwise PLS regression, R software (R_Development_Core_Team, 2004) for the cross-validation of PLS variables, and PPPhalos software (Guiot, 1991) for neural networks. 